\title{
CELEBRATING THE 50TH ANNIVERSARY OF PROFESSOR HERMANN SLEUMER'S CLASSIC TREATMENT OF THE ERICACEAE FOR FLORA MALESIANA
}

\author{
George Argent ${ }^{1}$
}

\begin{abstract}
The major taxonomic changes that have been made within the Ericaceae since the publication of Professor Sleumer's classic Flora Malesiana account are presented, as well as how these affect the Malesian region. Examples of Professor Sleumer's acuity in taxonomic research are cited.
\end{abstract}

The taxonomic treatment of the Ericaceae Juss. by Professor Hermann Sleumer is one of the most classic revisions published for Flora Malesiana, with over 700 species keyed and described. It remains a much-consulted standard work (Sleumer, 1966-1967) and was the culmination of a lifetime's interest in the family Ericaceae. This was interrupted by the Second World War after which Professor Sleumer took up residence in the Netherlands to pursue a special interest in the Malesian region and to produce this account (Fig. 1). Professor Sleumer was one of the many academics who had to flee Germany prior to the outbreak of the Second World War, and he resided in Argentina for the duration of the conflict. He moved to the Netherlands after the war as he saw little prospect of pursuing taxonomic work in Germany (de Wilde \& Baas, 1994).

Inevitably any good taxonomic treatment stimulates interest which in turn generates new collections and new ideas, potentially leading to taxonomic changes. This, coupled with the unprecedented changes in taxonomy thanks to comparative DNA sequence data, makes it hardly surprising that substantial changes have occurred in this family in the 50 years since the publication of Flora Malesiana. Professor Pieter Baas, in conversation some years ago, expressed the view that good taxonomic accounts did not get proper scientific credit as there was no record of the number of consultations or identifications made using taxonomic works in the way that the citation index reflects the usage of other scientific papers (Krell, 2000; Valdecasas et al., 2000). Professor Sleumer's Ericaceae would certainly get a very high ranking if records of these consultations were kept.

A large but disparate body of information had built up on the Ericaceae prior to the Flora Malesiana account with major contributions from Copeland (1929; 1930; 1932), Merrill (1908), Schlechter (1918) and Smith (1935). The first major change from the taxonomy in the account occurred when Dr Peter Stevens transferred Vaccinium L. section Pachyanthum Sleumer to Dimorphanthera Sleumer (Stevens, 1974) (Fig. 2). Although the flower shape in this group was short-campanulate like many vacciniums,

1. George Argent is a Research Associate at RBGE. Address: 20A Inverleith Row, Edinburgh, EH3 5LR. Email: GArgent@rbge.org.uk 
Fig. 1 Professor Hermann Sleumer in the Rijksherbarium, Leiden. Photo reproduced with the kind permission of the Naturalis Archives.

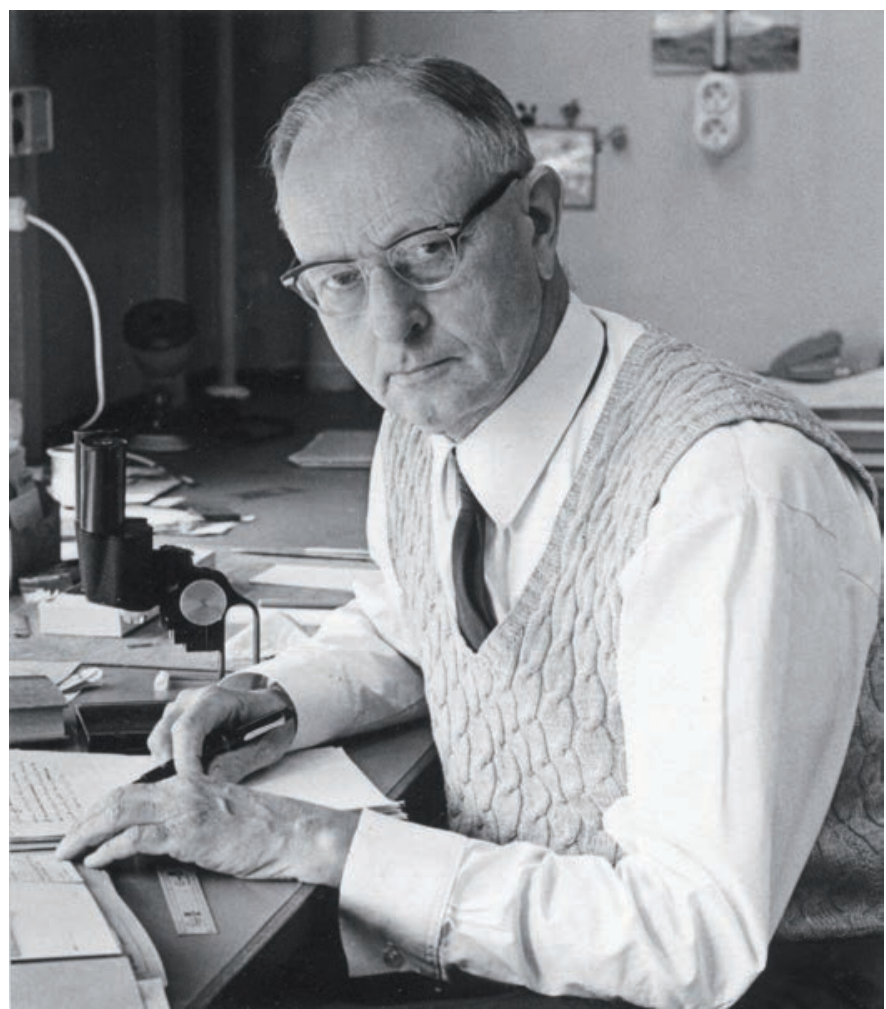

the bistratose structure of the corolla and the tough stamen structure suggested a much better fit in Dimorphanthera. Much later, Dr Stevens resurrected Paphia Seem. as a genus separate from Agapetes D.Don. Paphia had been described by Berthold Seemann in 1864. Dr Stevens argued that new information both molecular and morphological meant that Agapetes could not be maintained and "the reinstatement of Paphia does least violence nomenclaturally" (Stevens, 2003).

The small-flowered genus Diplycosia Blume now includes the genus Pernettyopsis King \& Gamble which was monotypic in Sleumer's account (Argent, 2002). Several new species of Diplycosia have been described, making it somewhat less centred on Borneo, especially Mt Kinabalu, although a new species has only just been described for that most accessible mountain (Fritsch \& Bush, 2016) and a second species of Gaultheria Kalm ex L. (Fritsch \& Bush, 2011). Molecular work (Powell \& Kron, 2001; Fritsch et al., 2011) shows that Diplycosia is nested within the more widespread genus Gaultheria (although these genera remain remarkably distinct in Malesia), suggesting that Gaultheria should be either split up or combined into a single genus together with the neotropical genus Tepuia Camp.

As one of the biggest, most showy genera, Rhododendron L. has received considerable attention since the Flora Malesiana account. Professor Sleumer was the first to 


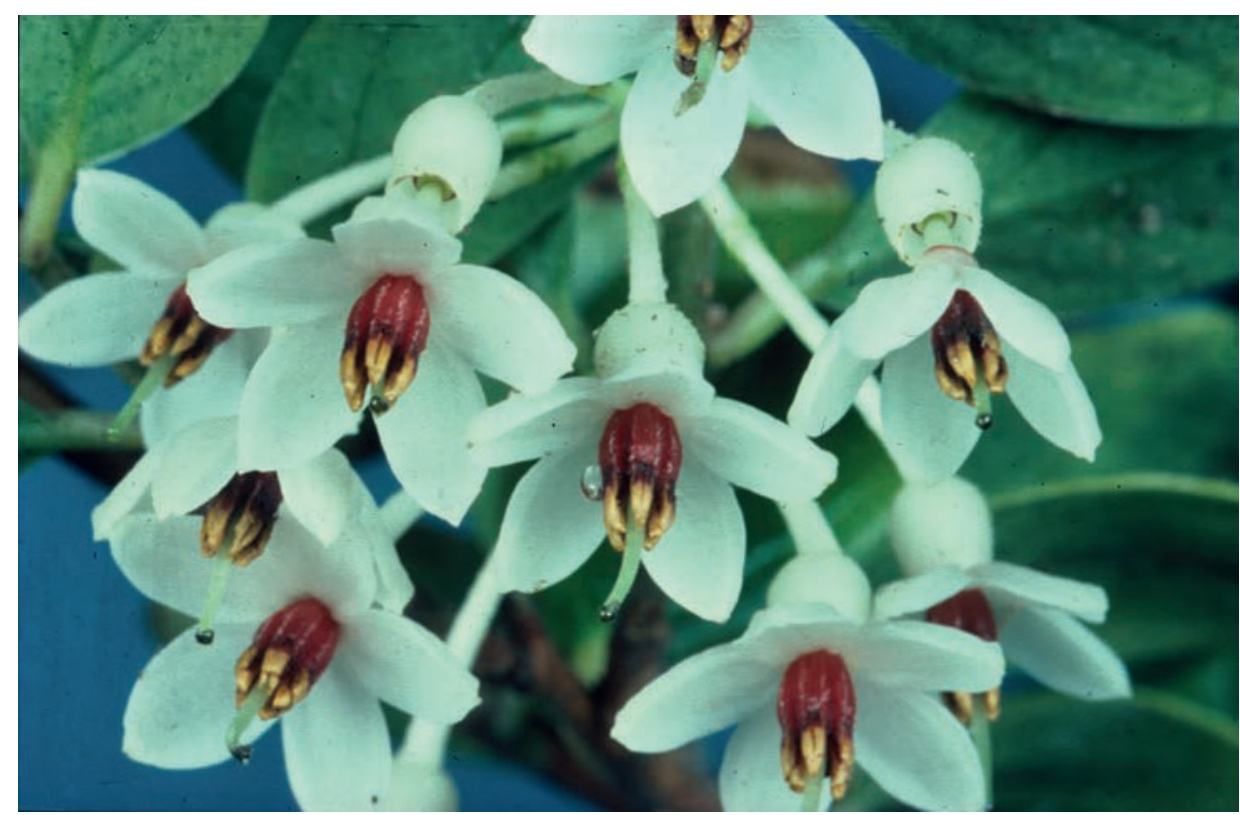

Fig. 2 Dimorphanthera amplifolia (F.Muell.) P.F.Stevens transferred from Vaccinium section Pachyanthum. Photo: (C) Royal Botanic Garden Edinburgh.

put the genus on a proper taxonomic footing worldwide (Sleumer, 1949). The vast influx of collections from China and the Himalaya in the late 19th and early 20th centuries had been classified in an unconventional series of groupings (Rehder et al., 1930). Professor Sleumer distinguished between the campanulate corollas of Pseudovireya Clarke from the cylindrical corollas of Discovireya Sleumer which he unaccountably amalgamated in his Flora Malesiana account. These groups have proved to be very distinct (Argent, 2006) and this has been confirmed with molecular work (Goetsch et al., 2005). Sleumer's Rhododendron account was essentially a practical way of managing the great number of new species that had to be accommodated and recent molecular work has significantly changed the groupings in Rhododendron with division of the bulk of the Malesian species into an eastern and western clade (Brown et al., 2006).

With the opening up of New Guinea, masses of new collections of herbarium material became available, allowing Professor Sleumer to describe over 100 new species of Rhododendron from the region, more than anyone else from subgenus Vireya. His careful dissections and close attention to detail provided an excellent taxonomic framework for the genus, which in many cases still allows accurate identification of species. Two examples of Sleumer's observational acuity can be cited. His separation of $R$. praetervisum Sleumer from a mass of dried $R$. longiflorum Lindl. specimens, based on differences in the distribution of hairs on the corolla observed only on herbarium specimens, was completely vindicated by subsequent observations on the living plants which revealed different habitats, flower colours and flower orientations (Fig. 3), i.e., $R$. 

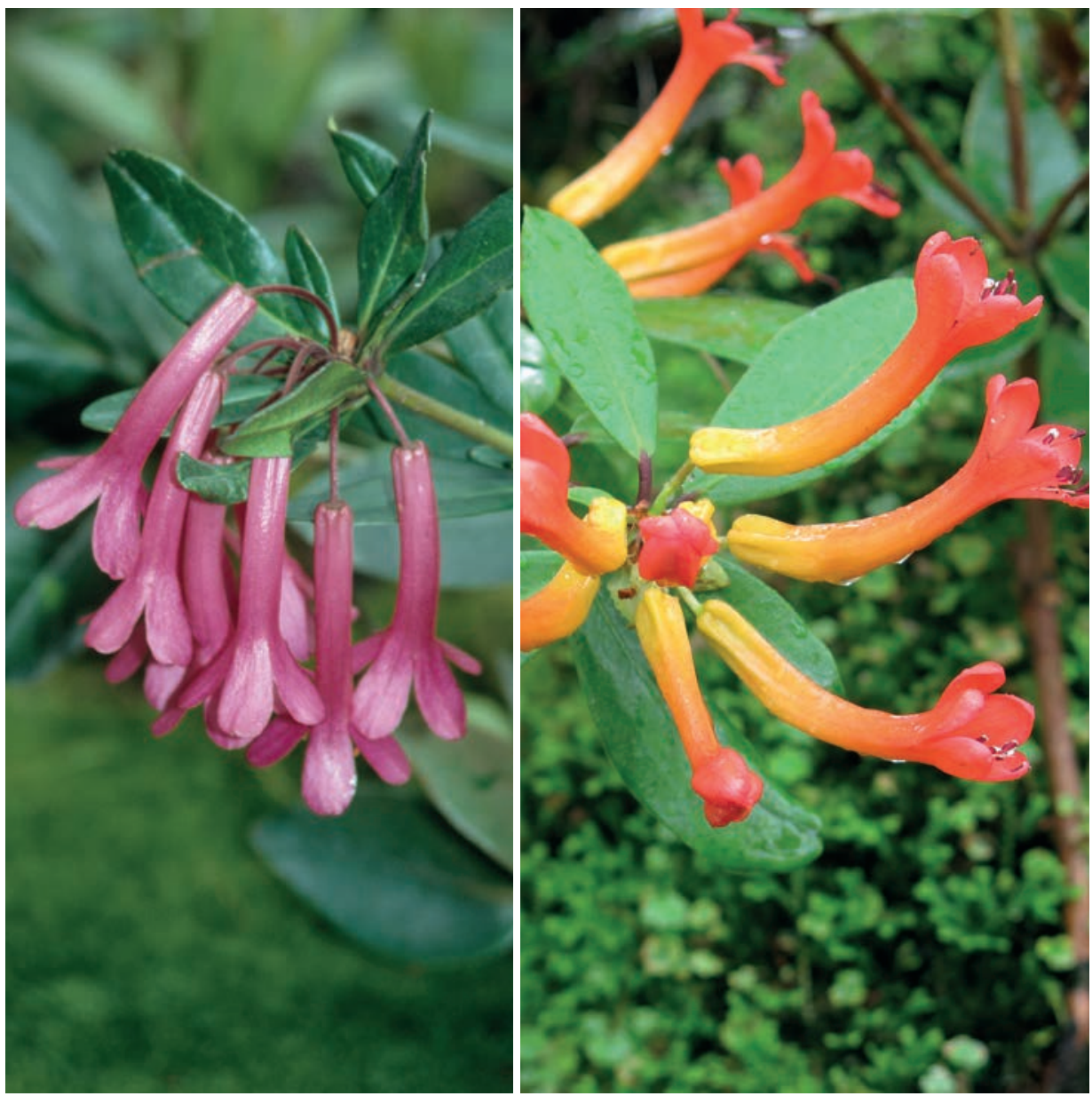

Fig. 3 Rhododendron praetervisum Sleumer (left) \& R. longiflorum Lindl. (right), showing the different colour and floral habits of these species. Photo: George Argent.

praetervisum flowers hanging and those of $R$. longiflorum (Fig. 3) spreading. The other example is his observation that $R$. micromalayanum Sleumer has more leathery leaves than the widespread and variable $R$. malayanum Jack. It was found under microscopic examination that $R$. micromalayanum has a double palisade layer whereas $R$. malayanum has just a single one. This difference was observed by Professor Sleumer using just his thumb and finger. Professor Sleumer certainly appreciated that Vireya rhododendrons were horticulturally attractive plants. When asked to by the Australian Rhododendron Society, he provided seeds to several botanic gardens as well as cuttings of the very impressive R. leucogigas Sleumer (Fig. 4), which caused a sensation when it first flowered in cultivation in Boskoop, Netherlands in 1964.

Another significant change to the Ericaceae since the Flora Malesiana account has been the inclusion of the Epacridaceae R.Br. (now subfamily Epacridoideae), a family 


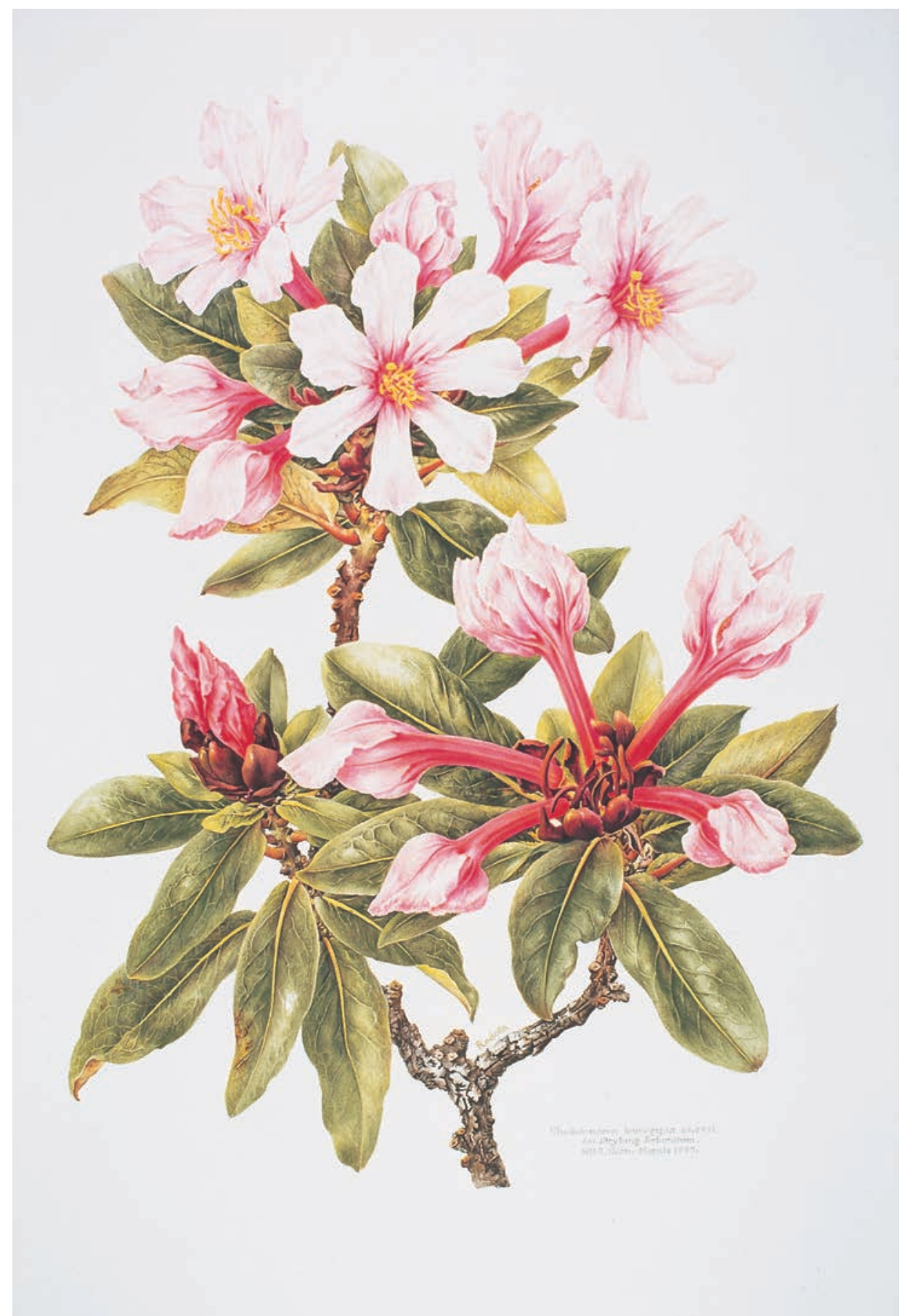

Fig. 4 Rhododendron leucogigas Sleumer; the first flowering in Edinburgh. Painting by Rodella Purves reproduced with the permission of the artist. 
which Sleumer had already revised for the Flora. The root morphology together with fungal mycotrophic association had suggested a very close relationship between these families which has been confirmed and emphasised by molecular work (APG II, 2003), although this is refuted by Watson \& Dallwitz (1992-), and continued the tradition of the Ericaceae in swallowing up the previously recognised families Monotropaceae Nutt., Pyrolaceae Lindl. and Vacciniaceae DC. ex Perleb.

Professor Sleumer did not restrict his interests to the Ericaceae but also made notable contributions to the families Escalloniaceae R.Br. ex Dumort., Flacourtiaceae Rich. ex DC., Icacinaceae Miers, Olacaceae R.Br., Myrsinaceae R.Br. and Proteaceae Juss. (de Wilde \& Baas, 1994).

Taxonomic accounts, however good, are always merely a snapshot of our understanding at one particular time. A good taxonomic account stimulates interest and often sows the seeds of its own obsolescence, but careful critical morphological observation remains a sound basis for all future work and will stand the test of time regardless of new interpretations.

I feel personally privileged to have met Professor Sleumer, who was a remarkably modest man. He made his field books available to me and these showed some remarkable insights into his very human character in addition to many careful observations. On seeing my first work on Bornean rhododendrons (Argent et al., 1988), he expressed profound interest in what he chose to call his 'mistakes'. These were merely some differences in interpretation which he did not choose to challenge as many in his eminent position might have done.

\section{REFERENCES}

APG II (2003). An update of the Angiosperm Phylogeny Group classification for the orders and families of flowering plants. Botanical Journal of the Linnean Society, 141: 399-346.

ARGENT, G. (2006). Rhododendrons of Subgenus Vireya. RBGE, Edinburgh.

ARGENT, G., LAMB, A., PHILLIPPS, A. \& COLLENETTE, S. (1988). Rhododendrons of Sabah. Sabah National Parks Publication, No. 8. Kota Kinabalu, Sabah.

ARGENT, G.C.G. (2002). New taxa and combinations in the genus Diplycosia (Ericaceae) of Borneo and Peninsular Malaysia. Gardens' Bulletin, Singapore, 54: 217-238.

BROWN, G.K., NELSON, G. \& LADIGES, P.Y. (2006). Historical biogeography of Rhododendron section Vireya and the Malesian archipelago. Journal of Biogeography, 33(11): 1929-1944.

COPELAND, H.F. (1929). Philippine Ericaceae I: The species of Rhododendron. Philippine Journal of Science, 40: 133-179, plates 1-15.

COPELAND, H.F. (1930). Philippine Ericaceae II. Philippine Journal of Science, 42: 537-607, plates $1-7$.

COPELAND, H.F. (1932). Philippine Ericaceae III: A taxonomic revision concluded. Philippine Journal of Science, 47: 57-117, plates 1-8. 
DE WILDE, W.J.J.O. \& BAAS, P. (1994). In memoriam H.O. Sleumer (1906-1993). Blumea, 38: 241-245.

FRITSCH, P.W. \& BUSH, C.M. (2011). A new species of Gaultheria (Ericaceae) from Mt. Kinabalu, Borneo, Malaysia. Novon, 21(3): 338-342.

FRITSCH, P.W. \& BUSH, C.M. (2016). Diplycosia rigidifolia sp. nov. (Ericaceae) from Borneo, Sabah, Malaysia. Nordic Journal of Botany, 34(6): 699-702.

FRITSCH, P.W., LU, L., BUSH, C.M., CRUZ, B.C., KRON, K.A. \& LI, D.-Z. (2011). Phylogenetic analysis of the wintergreen group (Ericaceae) based on six genic regions. Systematic Botany, 36(4): 990-1003.

GOETSCH, L.A., ECKERT, A.J. \& HALL, B.D. (2005). The molecular systematics of Rhododendron (Ericaceae): a phylogeny based on RPB2 gene sequences. Systematic Botany, 30(3): 616-626.

KRELL, F.T. (2000). Impact factors aren't relevant to taxonomy. Nature, 405: 507-508.

MERRILL, E.D. (1908). Philipppine Ericaceae. Philippine Journal of Science and Botany, 3: 369-382.

POWELL, E.A. \& KRON, K.A. (2001). An analysis of the phylogenetic relationships in the wintergreen group (Diplycosia, Gaultheria, Pernettya, Tepuia; Ericaceae). Systematic Botany, 26(4): 808-817.

REHDER, A., TAGG, H.F. \& HUTCHINSON, J. (1930). Species of Rhododendron. British Rhododendron Society. [Edinburgh].

SCHLECHTER, R. (1918). Die Ericaceen von Deutsch-Neu-Guinea. Botanische Jahrbücher, 55: 137-194.

SLEUMER, H. (1949). Ein System der Gattung Rhododendron L. Botanische Jahrbücher, 74: 511-553.

SLEUMER, H. (1966-1967). Ericaceae. Flora Malesiana, Ser. 1, Spermat., 6: 469-914.

SMITH, J.J. (1935). New Malaysian Ericaceae. Bulletin du Jardin botanique de Buitenzorg Ser. III, XIII: 443-464.

STEVENS, P.F. (1974). Circumscription and relationships of Dimorphanthera (Ericaceae) with notes on some Papuasian species. Contributions from Herbarium Australiense, 8: 1-34.

STEVENS, P.F. (2003). New taxa in Dimorphanthera and Paphia (Ericaceae) in Papuasia and the problem of generic limits in Vaccinieae. Edinburgh Journal of Botany, 60: 267-298.

VALDECASAS, A.G., CASTROVIEJO, S. \& MARCUS, L.F. (2000). Reliance on the citation index undermines the study of biodiversity. Nature, 403: 698 .

WATSON, L. \& DALLWITZ, M.J. (1992-). The families of flowering plants: descriptions, illustrations, identification and information retrieval, 20 July 2017. Available online: deltaintkey.com/angio (accessed 20 January 2018). 